\title{
Estudo das alterações relacionadas com a idade na pele humana, utilizando métodos de histo-morfometria e autofluorescência*
}

Study of age-related changes in human skin using histomorphometric and autofluorescence approaches*

\author{
Reinaldo B. Oriá \\ Mariana R. Fernandes
}

\author{
Francisco Valdeci A. Ferreira ${ }^{2}$ \\ Gerly A. C. Brito
}

\author{
Érika N. Santana
}

Resumo: Fundamentos - O processo de envelhecimento tecidual é evidente nas modificações visíveis na pele, resultando em importantes implicações psicológicas para o indivíduo e crescente interesse científico.

OBjETIVOS - $\mathrm{O}$ presente trabalho objetivou analisar as alterações da pele normal com o envelhecimento mediante estratégias de his tomorfometria e autofluorescência.

MÉTODOs - Foram coletadas amostras de pele do abdômen de 18 cadáveres, incluindo cinco indivíduos jovens (menos de 20 anos), sete indivíduos com idade intermediária (20-60 anos) e seis indivíduos idosos (mais de 60 anos). Foram feitos cortes histológicos em parafi na seguidos de coloração pela Hematoxilina-Eosina (H\&E) e pelo tricrômio de Van Gieson-elastina. Avaliaram-se a espessura da epiderme e derme, e a superfície de contato epidermo-dérmica. Investigaram-se ainda as modificações qualitativas do aparelho colágeno-elástico, considerando sua disposição espacial na derme. Espécimes corados em H\&E também foram utilizados para autofluorescência.

Resultados - A espessura da epiderme e derme do grupo idoso foi significativamente diminuída $(\mathrm{p}<0,05)$ em relação aos demais grupos. Os grupos idoso e intermediário exibiram acentuada redução na superfície de contato epiderme-derme $(\mathrm{p}<0,05)$. Detectaram-se a perda da distribuição em rede das fibras elásticas com sua progressiva fragmentação, alterações da compactação do colágeno e espessamento da membrana basal com o envelhecimento.

Conclusão - O envelhecimento leva à redução da espessura da derme e epiderme, bem como ao aplanamento da junção dermoepidérmica. As mudanças da pele ao longo da vida nem sempre seguem um perfil linear, mostrando drásticas alterações nas últi mas décadas de vida. O método de autofluorescência mostrou-se um instrumento valioso no estudo da complexa relação espacial das fibras elásticas e colágenas.

Palavras-chave: derme; envelhecimento; envelhecimento da pele; epiderme; pele.

\begin{abstract}
Summary: BACKGROUND - Age-related changes are easily recognized by examining the skin and lead to important psychological implications, motivating increased scientific interest.

OBJECTNES - This study aimed to analyze, by histomorphometric and autofluorescence approaches, the aged-related alterations in normal buman skin.

METHODS - Normal abdominal skin samples were taken from eighteen cadavers, including five young subjects (below 20 years old), seven subjects with intermediate age (20-60 years old) and six elderly subjects (over 60 years old). Paraffin-embedded sections were prepared and stained by Hematoxylin and Eosin (HEE) and Van Gieson-elastin trichrome. Afterwards, the HEE specimens were also used for autofluorescence technique.

RESULTS - The thickness of elderly epidermis and dermis was reduced compared to middle-aged and young age groups $(p<0.05)$. The elderly and middle-aged groups also showed a marked reduction in the epidermal-dermal contact surface $(p<0.05)$ in com parison to the young group. In addition, we detected a loss of the distribution in the elastic fiber network in the elderly with pro gressive fragmentation, as demonstrated by Weigert's stain for elastin and poor fluorescent contrast.

CONCLUSION - The thickness of the epidermis, dermis, and epidermal-dermal interface contact surface decreased in the aged skin. The changes throughout life in the normal skin did not follow a continuous linear profile, showing drastic alterations especiat ly in the last decades. Autofluorescence approach proved to be an important additional tool for studying the complex relationship between the elastic and collagen fibers.

Key-words: dermis; aging; skin aging; epidermis; skin.
\end{abstract}

Recebido em 27.08.2002. / Received in August, $27^{\text {h }}$ of 2002.

Aprovado pelo Conselho Consultivo e aceito para publicação em 01.04.2003. / Approved by the Consultive Council and accepted for publication in April, 01 ${ }^{\star}$ of 2003.

* Trabalho realizado no Departamento de Morfologia da Faculdade de Medicina da Universidade Federal do Ceará. / Work done at Mophology Department of "Faculdade de Medicina da

Universidade Federal do Ceará"

${ }^{l}$ Departmento de Morfologia, Universidade Federal do Ceará, Fortaleza, CE, Brasil. / Dept. of Morphology, Federal University of Ceará, Fortaleza, CE, Brazil

${ }^{2}$ Departmento de Patologia e Medicina Legal, Universidade Federal do Ceará, Fortaleza, CE, Brasil. / Dept. of Pathology and Legal Medicine, Federal University

of Ceará, Fortaleza, CE, Brazil.

${ }^{3}$ Estudantes de Medicina da Universidade Federal do Ceará, Fortaleza, CE, Brasil. / Medical Students, Federal University of Ceará, Fortaleza, CE, Brazil. 


\section{INTRODUÇÃO}

Os tecidos gradualmente passam por mudanças de acordo com a idade, sendo que, na pele, essas alterações são mais facilmente reconhecidas. ${ }^{1,2}$ Atrofia, enrugamento, ptose e lassidão representam os sinais mais aparentes de uma pele senil. . $^{3-5}$

Mudanças nas características da pele humana durante o envelhecimento são freqüentemente determinadas por forças ambientais ou extrínsecas, tais como radiação ultravioleta, ${ }^{6,7}$ assim como por fatores intrínsecos ${ }^{8-10}$ alguns deles relacionados com alterações no tecido conjuntivo da derme. ${ }^{11-13}$ Alterações no tecido conjuntivo, que atua como alicerce estrutural para epiderme, delineiam essas mudanças na aparência externa, que são refletidas no estrato córneo. ${ }^{14,15}$ As modificações do aparelho colágeno-elástico ao longo da vida estabelecem uma base morfológica substancial para compreender as adaptações bioquímicas e biomecânicas da pele com a idade. ${ }^{16-19} \mathrm{~A}$ espessura da pele e suas propriedades viscoelásticas não dependem apenas da quantidade de material presente na derme, mas também de sua organização estrutural. ${ }^{20,21}$

Para estudar os mecanismos envolvidos no envelhecimento, portanto, é necessário compreender melhor as mudanças estruturais e funcionais que ocorrem com o avançar da idade, distinguindo as alterações que possam representar um processo intrínseco daquelas que refletem efeitos patológicos cumulativos ou agressões ambientais externas. ${ }^{22,23}$ Convém ainda considerar que, independente da idade do indivíduo, a espessura total da pele, espessura relativa da epiderme e derme, distribuição e fenótipo da população celular na derme, presença de anexos cutâneos e densidade da microvasculatura e de nervos variam conforme a região do corpo. ${ }^{2426}$

Exames histológicos e ultra-estruturais da pele, a partir de espécimes obtidos por autópsia, documentam importantes alterações estruturais na epiderme, junção epidermo-dérmica, derme e anexos epidérmicos. Com intuito de investigar as mudanças cronológicas da pele humana, foram utilizados métodos de microscopia de fluorescência, a partir de coloração por H\&E e histomorfometria, possibilitando, dessa forma, retratar as modificações teciduais ao longo da vida, no que diz respeito a sua textura e conformação, relacionando com sua modelação biomecânica no espaço.

\section{MATERIAIS E MÉTODOS}

Amostras de pele foram coletadas de 18 cadáveres, incluindo cinco indivíduos jovens (abaixo dos 20 anos), sete indivíduos com idade intermediária (20-60 anos) e seis indivíduos idosos (com mais de 60 anos). Usaram-se como critérios de inclusão pacientes de ambos os sexos, sem discriminação de raça, cuja causa da morte não incluíssem doenças que afetam diretamente a pele. Foram excluídos do trabalho os indivíduos com doença dermatológica ou sistêmicas ligadas diretamente a alterações cutâneas

\section{INTRODUCTION}

Tissues gradually go through changes in accordance with age, and, in the skin, those alterations are more easily recognized. ${ }^{1,2}$ Atrophy, wrinkles, ptosis and looseness represent the most apparent signs of a senile skin. ${ }^{3.5}$

Changes in the characteristics of human skin during aging are frequently determined by environmental or extrinsic forces, such as ultraviolet radiation, ${ }^{6,7}$ as well as by intrinsic factors, ${ }^{8-10}$ some of them related with alterations in the conjunctive tissue of the dermis. ${ }^{11-13}$ Alterations in the conjunctive tissue which acts as a structural foundation for the epidermis, delineate these changes in the external appearance that are reflected in the corneum stratum. ${ }^{14,15}$ The modifications of the collagen-elastic apparatus throughout a lifetime establish a substantial morphological basis from which to understand the biochemical and biomechanical adaptations of the skin with age. ${ }^{16-19}$ The thickness of the skin and its viscoelastic properties do not depend only on the amount of material present in the dermis, but also on its structural organization. ${ }^{20,21}$

To study the mechanisms involved in aging, therefore, it is necessary to understand the structural and functional changes that occur with the advancement of age, distinguishing between the alterations that can represent an intrinsic process, and those that reflect cumulative pathological effects or external environmental aggressions. ${ }^{22,23}$ It is well to consider that, independent of the individual's age, the total thickness of the skin, relative thickness of the epidermis compared with the dermis, distribution and phenotype of the cellular population in the dermis, presence of cutaneous enclosures and density of the microvasculature and of nerves, can all vary according to which area of the body is being examined. ${ }^{2426}$

Histological and ultra-structural exams of the skin, based on specimens obtained by autopsy, document important structural alterations in the epidermis, dermoepidermal interface, dermis and epidermal annexes. With the intention of investigating the chronological changes in human skin, microscopic fluorescence techniques were used, starting from coloration by $H \& E$ and histomorphometry, making possible, in this way, to portray the tissue modifications along the course of a lifetime together with their implications regarding the changing textures and conformations, related to its spatial biomechanical modeling.

\section{MATERIAL AND METHODS}

Skin samples were collected from 18 cadavers, including five young individuals (below 20 years of age), seven individuals of middle-age (20-60 years) and six elderly individuals (more than 60 years of age). The inclusion criteria were patients of both sexes, without discrimination of race, whose cause of the death did not include diseases that affect the skin directly. Excluded from this work were individuals with dermatological disease or with case histories reporting systemic pathologies linked direct- 
relatadas no prontuário. Amostras de pele medindo $1 \mathrm{~cm}^{2}$ foram colhidas da região abdominal, $2 \mathrm{~cm}$ acima da cicatriz umbilical. Como indicado por Faria et al. ${ }^{27}$ e Gonçalves, ${ }^{1}$ a pele do abdômen é apropriada para o estudo das alterações causadas pelo processo de envelhecimento. Os espécimes foram obtidos durante o procedimento de autópsia realizado no Departamento de Patologia e Medicina Legal da Universidade Federal do Ceará (UFC). O protocolo experimental foi previamente aprovado pelo Comitê de Ética e Pesquisa do Hospital Universitário Walter Cantídio/UFC. As amostras de pele foram imediatamente fixadas em solução de formalina tamponada a $10 \%$ por $24 \mathrm{~h}$ e embebidas em parafina. Foram realizadas secções de seis micrômetros de espessura dos blocos de parafina; em seguida, as peças foram hidratadas após a remoção da parafina, coradas e montadas em meio de Entelan nas lâminas his tológicas. Todos os espécimes foram corados em H\&E para posteriormente serem analisados pelo método de autofluorescência. O método de Hematoxilina-Eosina e o tricrômio de Van Gieson-elastina, como descritos por Kiernan, ${ }^{28}$ foram escolhidos para estudar a morfologia da pele.

Os cortes histológicos de pele foram analisados utilizando um microscópio óptico binocular provido de ocular milimetrada (Leitz Wetzlar Germany Periplan, GF $\mathrm{x} 10$ ). Foram avaliadas a espessura da epiderme e derme, e a superfície de contato entre elas. A epiderme e a derme foram medidas em 10 diferentes locais em cada amostra: cinco medidas na papila e cinco nas cristas epidérmicas (Gráfico 1). A seguir, para cada corte foi ly to cutaneous alterations. Skin samples measuring $1 \mathrm{~cm}^{2}$ were collected from the abdominal areas, $2 \mathrm{~cm}$ above the umbilicus. As was indicated by Faria et al. ${ }^{27}$ and Gonçalves ${ }^{1}$, the skin of the abdomen is best adapted for the study of alterations caused by the aging process. The specimens were obtained during the autopsy procedure done in the Department of Pathology and Legal Medicine of the Federal University of Ceará (UFC). The protocol of the experiment was previously approved by the Committee of Ethics and Research of the Walter Cantidio/UFC Teaching Hospital. The skin samples were immediately placed in a $10 \%$ formalin buffer solution for 24 hours after which they were embedded in paraffin and six micrometers sections were made. The paraffin was then removed and the samples were moisturized, dyed and mounted on histological slides. All specimens were dyed with H\&E for later analysis by the autofluorescence method. The Hematoxylin and Eosin and Van Gieson-elastin trichrome methods, as described by Kiernan, ${ }^{28}$ were chosen for the study of the skin morphology.

The histological sections of skin were analyzed using a binocular optical microscope fitted with a millimeter scale (Leitz Wetzlar Germany Periplan, GF x10). The thicknesses of both the epidermis and dermis were measured, as well as the contact surface between them. The epidermis and the dermis were measured at 10 different sites in each sample: five measurements in the papillary layer and five in the layer of epidermic ridges (Graph 1). Following this, for each section a mean value
Gráfico 1: Diagrama ilustrando o método para análise morfométrica da epiderme, derme e superfície de contato epidermo-dérmica. Em cada amostra de pele, foram feitas 10 medidas da superfície da epiderme até a junção epidermederme, sendo cinco medidas na crista epidérmica (posicionando a ocular milimetrada conforme demonstrado na reta tracejada mar-cada com a letra a), e cinco medidas no nível da papila dérmica (conforme demonstrado com a letra b). Da mesma forma, foram feitas 10 medidas ao longo da derme em cada amostra de pele, sendo cinco medidas na papila dérmica (conforme demonstrado com a letra A), e cinco medidas no nível da crista epidérmica (conforme demonstrado com a letra B) até o limite da derme com a hipoderme (representada pelo limite inferior da figura). As médias a-ritméticas das 10 medidas da epiderme ou da derme por amostra foram utilizadas para o cál-culo da média de cada grupo. A extensão da superfície de contato epidermo-dérmica foi esti-mada pela soma das medidas realizadas ao longo de $20 \mathrm{~mm}$ de comprimento de cada prepara-do histológico, pelo posicionamento da ocular milimetrada tangencialmente às irregularidades da borda epitélio-conjuntiva conforme demonstrado nas retas marcadas com os algarismos 1 e 2 .

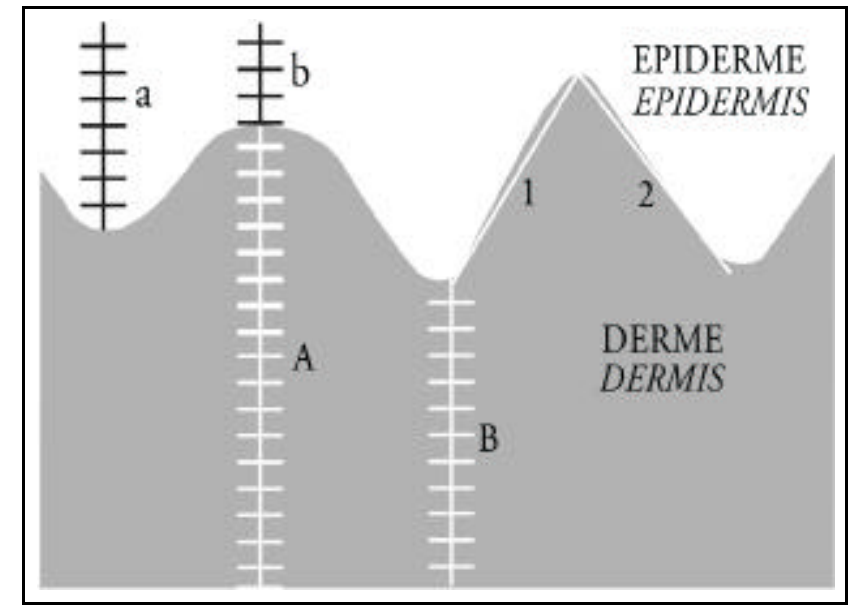

Graph 1 Diagram illustrating the method used to analyze the morphometry of the epider-mis, dermis and dermoepidermal interface. In each skin sample, 10 measurements were made of the epidermis interface, of which five were at the epidermal ridge level (positioning the ocular lens with millimetric grid as demonstrated in the line marked with the letter a), and five measurements at the papillary dermis level, as demonstrated with the letter $b$ ). In the same manner, 10 measurements were made along the dermis of each skin sample, of which five were at the papillary dermis level (as demonstrated with the letter A), and five measurements at the level of the epidermal ridge (as demonstrated with the letter B) up to the limit of the dermis with the hypodermis (represented by the lower limit of the figure). The arithmetic means of the 10 measurements of the epidermis or dermis per sample were used to calculate the mean for each group. The extension of the dermoepidermal interface was estimated by the sum of the measurements taken along the $20 \mathrm{~mm}$ length of each histological sample, by posi-tioning the ocular scale tangentially to the irregularities of the conjunctival-epithelial margin, as demonstrated by the lines marked with the algorithms marked 1 and 2. 
calculada uma média das medidas da espessura da epiderme e da derme, utilizada então para obtenção da média de cada grupo. A estimativa da junção epidermodérmica foi analisada, medindo-se a extensão da superfície de contato, ao longo de $20 \mathrm{~mm}$ de comprimento, pela disposição de linhas retas, seguindo tangencialmente as irregularidades da borda epitélio-conjuntiva. Estas medidas (espessura da epiderme, derme e estimativa da junção epidermo-dérmica) foram realizadas posicionando a ocular contendo uma reta milimetrada nas posições ilustradas na gráfico 1 .

As fibras elásticas foram estudadas pela técnica de Van Gieson-elastina, fazendo-se então uma análise qualitativa do componente elástico reticular nas amostras de pele, considerando sua distribuição, disposição e integridade.

A autofluorescência foi realizada nos cortes corados em H\&E da pele normal do abdômen, utilizando-se um microscópio de fluorescência da marca Leica, operando com luz transmitida. A fluorescência dos cortes corados em H\&E foi examinada por excitação/emissão de luz ultravioleta e pelo uso de filtros de barreira 420/530 para fluorescência verde, selecionados por causa do aumento na qualidade da resolução, como descrito por Carvalho et al. ${ }^{29}$

\section{Análise Estatística}

Os achados morfométricos foram avaliados utilizando o teste de análise de variância ANOVA, seguido pelo teste de Bonferroni. $\mathrm{O}$ valor de $\mathrm{p}<0,05$ foi considerado de significância mínima para todas as análises estudadas.

\section{RESULTADOS}

\section{Análise Histomorfométrica}

No presente estudo detectou-se que a espessura da epiderme no grupo idoso $(0,059 \pm 0,006 \mathrm{~mm})$ foi estatisticamente inferior $(\mathrm{p}<0,05)$ à espessura da epiderme dos grupos jovem $(0,094 \pm 0,003 \mathrm{~mm})$ e intermediário $(0,080 \pm$ $0,006 \mathrm{~mm}$ ) (Gráfico 2A). De forma semelhante, a espessura da derme no grupo idoso $(1,798 \pm 0,306 \mathrm{~mm})$ foi estatisticamente inferior $(\mathrm{p}<0,05)$ à dos grupos jovem $(2,716 \pm$ $0,217 \mathrm{~mm})$ e intermediário $(2,687 \pm 0,112 \mathrm{~mm}$ ) (Gráfico 2B). Os grupos idoso $(22 \pm 0,6 \mathrm{~mm})$ e intermediário $(30,2 \pm$ $2 \mathrm{~mm})$ exibiram uma redução significativa $(\mathrm{p}<0,05)$ da superfície de contato epidermo-dérmica em comparação ao grupo jovem $(41,4 \pm 2,46 \mathrm{~mm})$ (Gráfico 3 ). Não houve diferença estatística entre os grupos jovem e intermediário nas medidas morfométricas, com exceção da avaliação da superficie de contato epidermo-dérmica.

\section{Métodos de Coloração e Análise por Autofluo- rescência}

Epiderme e Junção Epidermo-Dérmica

A avaliação qualitativa dos preparados histológicos demonstrou acentuada redução da espessura da epiderme na was calculated for the measurements of the thicknesses of the epidermis and dermis. This was then used to obtain the mean of each group. The estimation of the dermoepidermal interface was analyzed by measuring the extent of the contact surface, along $20 \mathrm{~mm}$ of its length, using straight lines, but following tangentially the irregularities of the epithelium-conjunctive junction. These measurements (thickness of the epidermis, dermis and estimation of the dermoepidermal interface) were accomplished by positioning the ocular lens containing a scale marked in millimeters, in the positions shown in graph 1.

Elastic fibers were studied by Van Gieson-elastin technique, a qualitative analysis being made of the reticular elastic component in the skin samples, considering distribution, disposition and integrity.

Autofluorescence was performed in the sections of the normal skin of the abdomen dyed with H\&E. A Leica fluorescence microscope was used; operated with transmitted light. The fluorescence of the sections dyed with $H \& E$ was examined for excitation/emission of ultraviolet light and with the use of 420/530 barrier filters for green fluorescence. These were selected because of the increase in quality of the resolution, as described by Carvalho et al. ${ }^{29}$

\section{Statistical analysis}

The morphometric findings were evaluated using the variance analysis test ANOVA, followed by the Bonferroni test. A value of $p<0.05$ was considered the minimum for statistical significance in all of the analyses studied.

\section{RESULTS}

\section{Histomorphometric Analysis}

In the present study it was found that the thickness of the epidermis in the elderly group $(0.059 \pm 0.006 \mathrm{~mm})$ was statistically less $(p<0.05)$ than the thickness of the epidermis of the two other groups: young $(0.094 \pm 0.003 \mathrm{~mm})$ and middleaged: $(0.080 \pm 0.006 \mathrm{~mm})$ (Graph $2 \mathrm{~A})$. Likewise, the thickness of the dermis in the elderly group $(1.798 \pm 0.306 \mathrm{~mm})$ was statistically inferior $(p<0.05)$ to that of the young $(2.716 \pm$ $0.217 \mathrm{~mm})$ and middle-aged $(2.687 \pm 0.112 \mathrm{~mm})$ (Graph $2 B)$. The elderly $(22 \pm 0.6 \mathrm{~mm})$ and middle-aged $(30.2 \pm 2 \mathrm{~mm})$ groups exhibited a significant reduction $(p<0.05)$ of the surface of the dermoepidermal interface in comparison with the young group (41.4 $\pm 2.46 \mathrm{~mm})$ (Graph 3). There was no statistical difference between the young and middle-aged groups in morphometric measurements, except for the evaluation of the surface of the dermoepidermal interface.

\section{Methods of Coloration and Analysis by Autofluo- rescence \\ Epidermis and Dermoepidermal Interface}

The qualitative evaluation of the histological preparations demonstrated marked reduction of the thickness of 


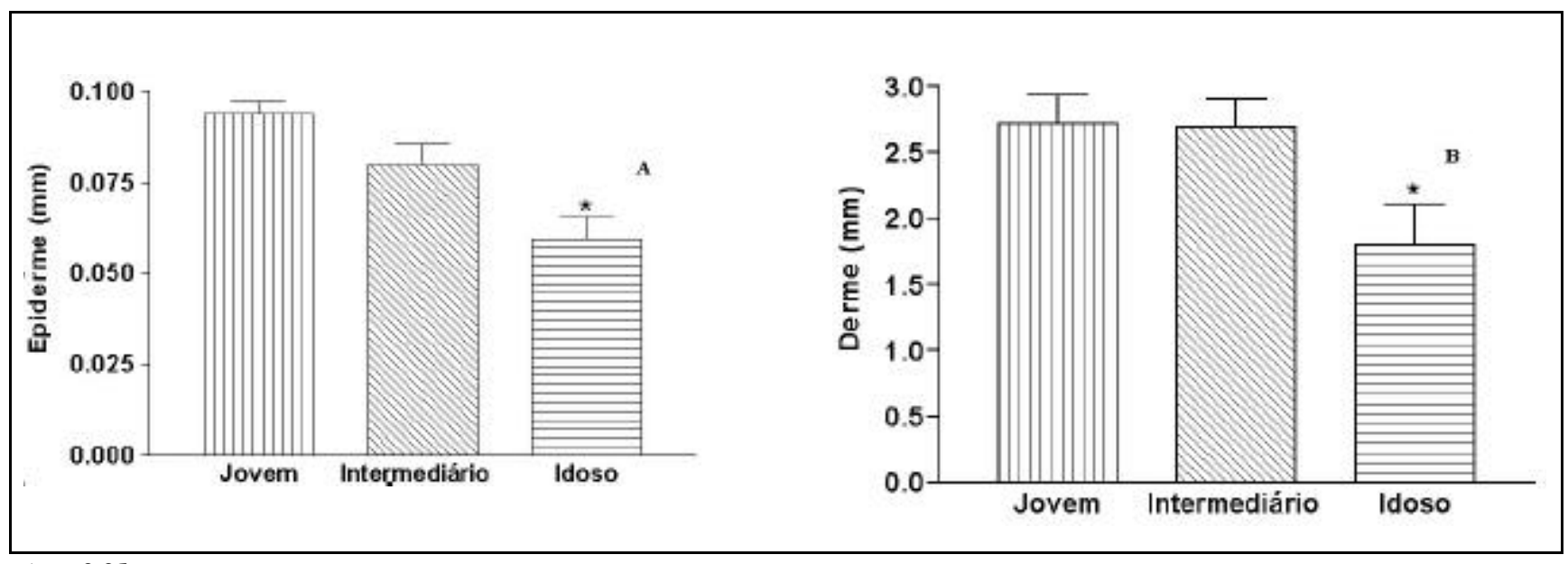

$* \mathrm{p}<0.05$

Gráfico 2: Efeito do processo de envelhecimento na espessura da epiderme e derme no grupo jovem (até 20 anos), grupo intermediário (20-60 anos) e no grupo idoso (acima de 60 anos). As medidas foram feitas em 10 diferentes locais, cinco nas papilas dérmicas, e cinco nas cristas epidérmicas, utilizando-se uma ocular histométrica (Leitz Wetzlar Ger-many Periplan GF x10) e uma objetiva de ampliação x10 para a derme e de ampliação x40 para epiderme. As barras representam média \pm erro padrão da espessura (mm) nos grupos estudados em relação à epiderme (A) e derme (B) pelo teste ANOVA Bonferroni. / Grapb 2: Effect of the aging process on the thickness of the epidermis and dermis in the young group (up to 20 yrs), Middle-aged group (20-60 yrs) and in the Elderly group (over 60 yrs). The measurements were taken at ten different sites, of which five at the level of the pap-illary dermis and five at the epidermal ridge level, using a bistometric ocular lens (Leitz Wetzlar Germany Periplan GF x10) and a 10X objective lens and 40x amplification for the epidermis. The bars represent the mean and \pm standard error of the thickness ( $\mathrm{mm}$ ) in the groups in relation to the epidermis (A) and dermis (B) using the ANOVA Bonferroni test.

pele senil e ausência do arranjo compacto dos queratinócitos, especialmente ao longo dos estratos de Malpighi. Além disso, observaram-se um arranjo desorganizado e achatamento das células basais, com menor acúmulo de melanosomas e menor densidade de melanócitos no grupo senil (Figuras 1B e 3B) quando comparado com o grupo jovem (Figuras 1A e 3A) ou intermediário (dado não mostrado). Detectou-se ainda redução da sinuosidade do trajeto da epiderme ao longo do comprimento da superfície dérmica, ilustrado por uma disposição grosseiramente linear da junção epidermo-dérmica (Figuras 1B e 2B) quando comparado com o grupo jovem (Figuras $1 \mathrm{~A}$ e 2A). A membrana basal apareceu mais bem definida na pele senil, con- the epidermis in senile skin and an absence of a compact arrangement of keratinocytes, especially along the Malpighian strata. Also a disorganized arrangement and a flattening of the basal cells were observed, with a lessened accumulation of melanosomes and a lower density of melanocytes in the senile group (Figures $1 B$ and $3 B$ ) when compared with the young group (Figures $1 A$ and $3 A$ ) or the middle-aged (data not shown). Furthermore, a reduction was detected in the sinuosity of the area covered by the epidermis along the length of the dermic surface, revealing a coarse linear disposition of the dermoepidermal interface (Figures $1 B$ and $2 B$ ) when compared with that of the young group (Figures $1 A$ and 2A). The basal cell membrane appeared to
Gráfico 3: Medida estimada da superfície de contato epidermodérmica do grupo jovem (até 20 anos), grupo intermediário (20-60 anos) e do grupo idoso (acima dos 60 anos). As medidas foram feitas em $20 \mathrm{~mm}$ de comprimento ao longo do campo histológico, pela disposição de linhas retas seguindo tangencialmente às irregularidades da borda epitélio-conjuntiva. As bar-ras representam a média \pm erro padrão da superfície de contato epidermodérmica $(\mathrm{mm})$ pelo teste de ANOVA Bonferroni.

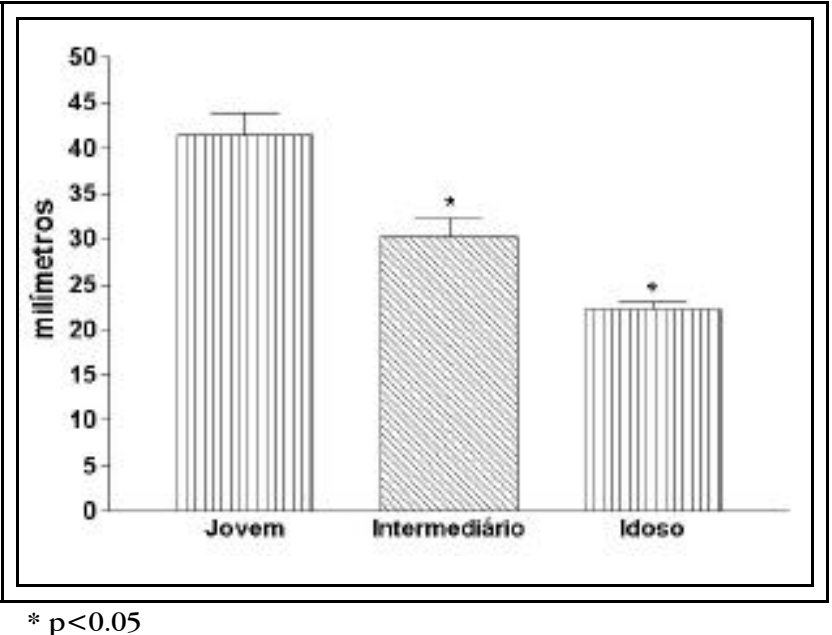

$* \mathrm{p}<0.05$
Graph 3: Estimated size of the dermoepidermal interface in the young group (up to 20 yrs), middle-aged group (2060 yrs) and elderly group (over 60 yrs). The measurements were taken along the $20 \mathrm{~mm}$ length of the histological field, using the straight lines tangentially following the irregularities of the conjunctive-epithelial margin. The bars represent the mean and \pm standard error of the dermoepidermal interface (mm) using the Bonferroni ANOVA test. 
Figura 1: Espécimes de pele dos grupos jovem (A) e idoso (B) corados pelo tricrômio de Van Giesonelastina, $\mathrm{x} 200$, em que as fibras elásticas são observadas em preto. Note-se a

clara fragmentação das fibras elásticas ao longo da derme com o envelhecimento. Na derme superfi-

cial, o aparelho elástico perdeu quase completamente sua disposição vertical na pele senil

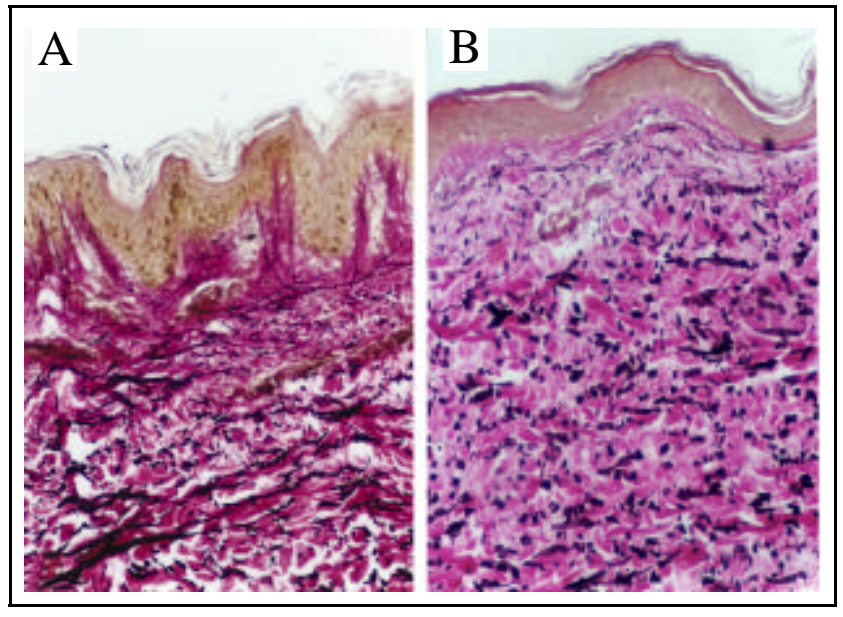

Figure 1: Skin specimens from the young (A) and elderly groups (B) using Van Gieson-elastin trichrome stain, $x 200$, in which the elastic fibers are visualized in black. Note the clear fragmentation of the elastic fibers along the dermis with aging. In the superficial dermis, the elastic apparatus has almost completely lost its vertical disposition in the aged skin. forme observação pelo acúmulo de fluorescência (Figura 3B - seta).

\section{Derme (aparelho colágeno-elástico)}

Em toda extensão da derme do grupo senil foi detectada fragmentação acentuada das fibras elásticas coradas em negro pela coloração de fucsina-resorcina de Weigert (Figura 1B), em contraste com o aspecto contínuo das fibras elásticas dos espécimes do grupo jovem (Figura 1A). As fibras elásticas, nos preparados de pele do grupo dos idosos, apresentavam-se mais frouxamente dispersas e com uma diminuição no entrançamento em relação às fibras colágenas, conforme demonstração pelo contraste fluorescente diminuído (Figura 3B). Além disso, ao longo das rasas papilas dérmicas, foi confirmada a deficiência do mecanismo de ancoragem em ângulo reto das fibras elásticas, ao longo do contorno em campânula do ápice papilar nos preparados dos indivíduos idosos (Figuras $1 \mathrm{~B}$ e $3 \mathrm{~B}$ ) em contraste com o arranjo das fibras elásticas dos espécimes do grupo jovem (Figura 1A). No grupo senil, os feixes colágenos estavam menos compactados e ondulados na região média da derme (Figuras $1 \mathrm{~B}^{*}$ e $3 \mathrm{~B}^{*}$ ), e o aparelho colágeno-elástico reticular mostrou-se mais susceptível à dispersão. Contudo, um arranjo mais compacto e espesso do apar- be better defined in senile skin, judging by the visibility of the accumulation of fluorescence (Figure $3 B$ - arrow).

\section{Dermis (elastic-collagen apparatus)}

Throughout the extension of the dermis in the senile group marked fragmentation of the elastic fibers was detected; these were dyed black by Weigert's stain for elastin (fuchsin and resorcin) (Figure 1B). This was in contrast with the continuous aspect of the elastic fibers of the specimens from the young group (Figure 1A). Elastic fibers, in the preparations of skin of the elderly group, were more loosely dispersed and less interlaced in relation to collagen fibers, as was demonstrated by a reduced fluorescent contrast (Figure 3B). Besides this, it was found that among the shallow dermal papillae there was a deficiency in the anchorage mechanism. This was confirmed by the right angle of the elastic fibers along the outline of the papillar apex in the preparations from elderly individuals (Figures $1 B$ and $3 B$ ) in contrast with the arrangement of elastic fibers of specimens from the young group (Figure 1A). In the senile group, collagen bundles were undulated and less compacted in the area in the middle of the dermis (Figures $1 B^{*}$ and $3 B^{*}$ ), and the collagen-elastic reticular apparatus was shown to be more susceptible to dispersion. Nevertheless, a more compact and
Figura 2: Espécimes de pele corados por $\mathrm{H} \& \mathrm{E}$, mostrando autofluorescência na derme superficial e média nos grupos jovem

(A) e idoso (B), x200.

Notem-se a redução considerável do contraste fluorescente na derme média (asterisco) e um componente fluorescente mais evidente no sítio da membrana basal na $\mathrm{p}$ ele senil (seta)

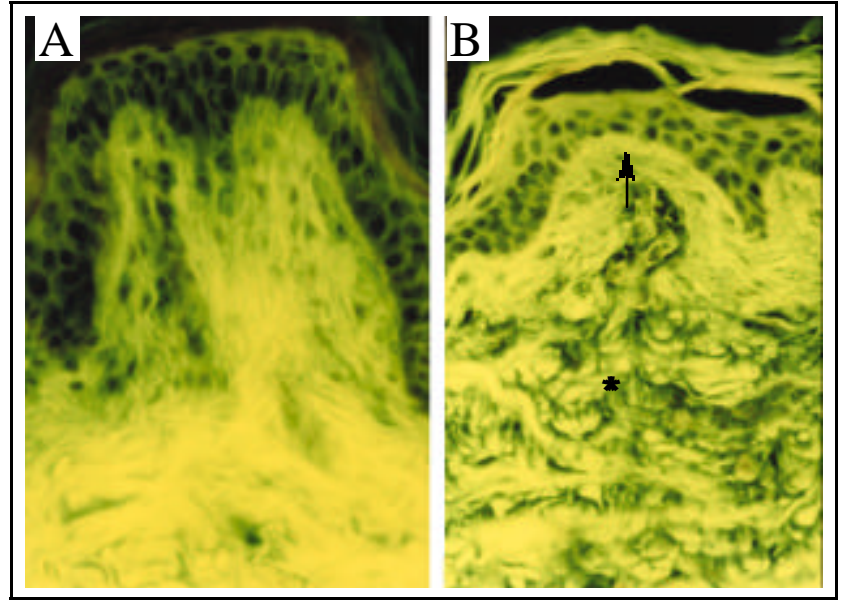

Figure 2: Skin specimens stained with HEE, showing autofluorescence at the level of the superficial and middle dermis in the young (A) and elderly (B) groups, $x 200$. Note the con-siderable reduction of the fluorescent contrast in the middle dermis (asterisk) and a fluores-cent component more evident in the site of the basement membrane in aged skin (arrow) 
Figura 3: Espécimes de pele dos grupos jovem (A) e idoso (B) corados por H\&E, x100. No-temse o achatamento progressivo da junção epidermo-dérmica com o envelhecimento e a redução da acidofilia na derme média

(asterisco), refletindo a redução da densidade de fibras colágenas.
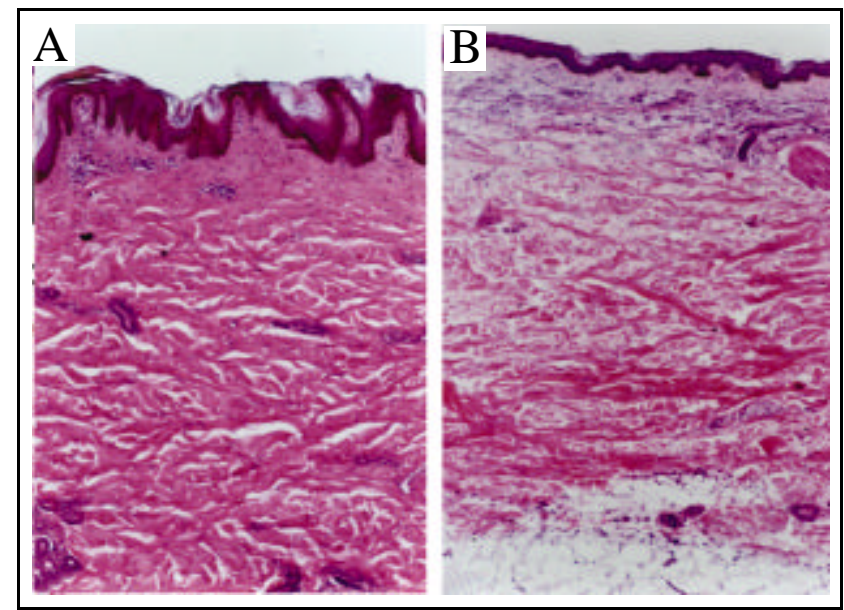

Figure 3: Skin specimens from the young (A) and elderly (B) groups, stained with $H E E, x 100$. Note the progressive flattening of the

dermoepidermal interface with aging and the re-duction of the acidophilia in the middle dermis (asterisk), reflecting the reduction in the den-sity of the collagen fibers. elho colágeno pode ser visto na derme profunda do grupo senil, ilustrado pela crescente coloração acidofílica (Figura 2B). No grupo senil, a derme superficial exibiu redução em sua celularidade e extensão em alça da microvasculatura papilar, revelada pelo discreto declínio da fluorescência local (Figura 3B).

\section{DISCUSSÃO}

O presente estudo documentou as alterações histológicas da pele de cadáveres durante o processo de envelhecimento, mediante estratégias de histomorfometria e autofluorescência. Observou-se redução significativa da espessura da epiderme e derme na pele de idosos, ilustrada pelos resultados histomorfométricos e análise qualitativa dos preparados corados por diversos métodos. Esse achado foi similar ao encontrado por outros autores. ${ }^{30,31}$ É importante considerar que algumas alterações estruturais da pele são inerentes ao envelhecimento, enquanto outras estão relacionadas à exposição ao sol, influências ambientais, grau de nutrição ou alterações do estado de saúde, como doenças endócrinas. Cabe também levar em conta as diferenças relacionadas à região do corpo estudada, especialmente no que diz respeito à espessura da pele. Os resultados obtidos pelos autores, em relação à pele do abdômen no grupo jovem, foram semelhantes aos descritos por Shuster et al. ${ }^{30}$ Esses autores, utilizando pele do antebraço, também detectaram diminuição na espessura da pele com o avançar da idade. Os resultados do presente trabalho mostram que a redução da espessura da epiderme e derme foi uma característica das últimas décadas de vida, evidência demonstrada pela ausência de diferença estatística entre os valores morfométricos na pele de indivíduos jovens e de idade intermediária. Achados semelhantes foram encontrados por Shuster et al. ${ }^{30}$ para indivíduos do sexo feminino.

De forma diversa, o aplanamento da derme papilar parece ocorrer progressivamente ao longo da vida, conforme observação qualitativa dos preparados histológicos estudados neste trabalho (dados não mostrados para o grupo intermediário), bem como pela redução já estatisticamente significante entre os grupos jovem e inter- thick arrangement of the collagen apparatus was seen in the deep dermis of the senile group, as illustrated by the increased acidophilic coloration (Figure 2B). In the elderly group, the superficial dermis presented a reduction in its cellularity and extension of the papillar microvasculature, as revealed by the discreet decline of local fluorescence (Figure 3B).

\section{DISCUSSION}

The present study, using the skin of cadavers, documented the histological alterations occurring during the aging process. Techniques of histomorphometry and autofluorescence were utilized.

A significant reduction of the thickness of the epidermis and dermis was observed in the skin of the elderly, as shown by the results of histomorphometry and qualitative analysis applied to preparations dyed by several methods. This finding was similar to that reported by other authors. ${ }^{30,31}$ It is important to consider that some structural alterations of the skin are inherent to the aging process, while others are related to sun exposure, environmental influences, levels of nutrition or alterations in the state of health, such as endocrinal diseases. It is also necessary to take into account the differences related to the area of the body studied, especially regarding the thickness of the skin. The results obtained by the authors, in relation to the skin of the abdomen in the young group, were similar to those described by Shuster et al. ${ }^{30}$ These authors, using skin of the forearm, also detected a decrease in thickness of the skin with advancement of age. The results of the present work show that the reduction of the thickness of the epidermis and dermis are a characteristic of the last decades of life, demonstrated by an evident absence of statistical difference between the morphometric values in the skin of young individuals and that of the middle-aged. Similar findings were reported by Shuster et al. ${ }^{30}$ for female individuals.

In several ways, the flattening of the papillar dermis seems to occur progressively throughout life, according to qualitative observation of the histological preparations studied in this work (data not shown for the middle-aged group). In addition, there is a reduction that is statistically 
mediário, da estimativa da superfície epidermo-dérmica. O grupo dos indivíduos de idade intermediária e idosos apresentou redução acentuada da superfície de contato epidermo-dérmica em relação ao grupo dos jovens, o que significa que a pele de indivíduos jovens apresenta maior quantidade de papilas dérmicas, com saliências e reentrâncias, comparativamente à pele de indivíduos idosos e intermediários. Isso pode ser explicado, de acordo com Tsuji \& Hamada, ${ }^{13}$ pela presença de um arranjo vertical de fibras nas papilas dérmicas que prendem a epiderme à derme dos indivíduos jovens, que é perdido nos idosos, fazendo com que a junção dermo-epidérmica se torne mais achatada e frágil. Essa alteração do arranjo das fibras elásticas foi claramente confirmada nos achados apresentados aqui, que mostram o desaparecimento do arranjo axial-vertical das fibras elásticas na derme dos indivíduos idosos, juntamente com acentuada e evidente fragmentação dessas fibras. Esses resultados foram similares ao de outros autores ${ }^{20,31,32}$ que relataram um contínuo colapso das propriedades elásticas na pele senil, pela falha da disposição em um padrão reticular, apesar da maior compactação dessas fibras, vista particularmente na derme profunda. De acordo com Imayama \& Braverman, ${ }^{32} \mathrm{o}$ arranjo tridimensional do aparato elástico, analisado por microscopia eletrônica de varredura, exibe fibras elásticas mais fragmentadas e porosas com a idade, conseqüentemente comprometendo a elasticidade da pele normal. O processo de fragmentação das fibras elásticas e de redução da espessura da epiderme e derme foi acelerado nas últimas décadas de vida, fato que foi evidenciado pela ausência de diferença estatística entre os valores morfométricos na pele de indivíduos jovens e de idade intermediária. Entretanto, as forças biomecânicas envolvidas no aplanamento da derme papilar parecem atuar progressivamente ao longo da vida, tendo em vista o contínuo declínio da superfície de contato epidermo-dérmica.

A coloração por $\mathrm{H} \& \mathrm{E}$ associada à microscopia de fluorescência, como descrito por Carvalho et al., ${ }^{29}$ ajudaram a esclarecer a complexa disposição da rede elástica e sua relação espacial com o colágeno. $\mathrm{O}$ entrançamento dos ramos das fibras elásticas em torno dos feixes de colágeno visto na pele jovem, a partir da autofluorescência, corrobora esses dados, sugerindo que ambos os componentes fibrosos estão incluídos num único sistema biomecânico, atuando conjuntamente. A compactação aumentada do colágeno, observada na derme profunda, em relação ao nível médio da derme, poderia ser explicada pelo maior número de ligações intermoleculares cruzadas, interagindo ao longo da matriz colagênica ${ }^{26,33,34} \mathrm{e}$, portanto, lentificando o turn over do colágeno nessa área, com o envelhecimento. Essa modificação durante a vida pode ser regionalmente específica. O padrão sinuoso dos feixes de colágeno parece ser mantido pela conexão com as fibras elásticas ao longo de suas concavidades ${ }^{15}$ portanto, a aparência ondulada do colágeno poderia ser afetada pelo colapso do aparelho elástico através da derme reticular em função da idade, levando significant between the young and middle-aged groups, seen in the estimation of the dermoepidermal surface. Individuals of the middle-aged group and the elderly presented accentuated reduction of the dermoepidermal contact surface in relation to the young group, which means that the skin of young individuals presents a larger amount of dermal papillae, with protuberances and cavities, compared to the skin of elderly and middle-aged individuals. This can be explained, according to Tsuji \& Hamada, ${ }^{13}$ by the presence of a vertical arrangement of fibers in the dermal papillas that secures the epidermis to the dermis in young individuals. This is lost in the elderly, causing the dermoepidermal interface to become flatter and more fragile. Alteration of the arrangement of the elastic fibers was clearly confirmed in the findings presented here, which show that in the dermis of elderly individuals there is a disappearance of the axial-vertical arrangement of the elastic fibers, as well as having accentuated and evident fragmentation of these fibers. Again these results were similar to those of other author ${ }^{20,31,32}$ that reported a continuous collapsing of the elastic properties in senile skin, due, in spite of the greater compacting of those fibers, to a failure to achieve disposition in a reticular pattern; this is seen particularly in the deeper dermis. According to Imayama \& Braverman, ${ }^{32}$ the three-dimensional arrangement of the elastic apparatus, analyzed by scanning electron microscopic, presents elastic fibers more and more fragmented and porous with age, consequently compromising the elasticity of normal skin. The process of fragmentation of the elastic fibers and reduction of the thickness of the epidermis and dermis is accelerated in the last decades of life, a fact that was evidenced by the absence of statistical difference between the morphometric values in the skin of young individuals and the middle-aged. However, the biomechanical forces involved in the flattening of the papillar dermis seem to act progressively along the course of life, keeping in mind the continuous decline of the dermoepidermal contact surface.

The coloration with $H \& E$ associated with fluorescent microscopy, as described by Carvalho et $\mathrm{al}^{29}$ helped to explain the complex disposition of the elastic network and its spacial relationship with collagen. The interlacing of the bundles of elastic fibers around the bundles of collagen seen in young skin, revealed by autofluorescence, corroborates these data, suggesting that both fibrous components are included in a single biomechanical system, acting jointly. The increasing compacting of collagen with aging observed in the deeper dermis, in relation to that in the medium level of the dermis, could be explained by the larger number of crossed intermolecular connections, interacting along the collagen matrix $x^{20,33,34}$ and, therefore, slowing the turn over of collagen in that area. This modification during a lifetime may be regionally specific. The sinuous pattern of the bundles of collagen seems to be maintained by the connection with the elastic fibers along their concavities; ${ }^{15}$ therefore, the undulated appearance of the collagen could be altered by the collapse of the elastic apparatus with- 
a uma predominante horizontalização, seguindo uma tendência linear. ${ }^{19} \mathrm{O}$ comprometimento do colágeno superficial e intermediário e da estrutura do tecido elástico poderia contribuir, dessa forma, com os quadros de ptose e de enrugamento tão bem caracterizados na velhice. De acordo com dados anteriores, ${ }^{35}$ no presente trabalho foi também identificado o aumento da autofluorescência na membrana basal epidermo-dérmica da pele senil, o que poderia ser explicado pelo crescente depósito de um componente fluorescente e pelo aumento de sua espessura total com a idade, o que reforça ainda mais a premissa do turn over deficiente do colágeno. ${ }^{34}$

\section{CONCLUSÃO}

Utilizando técnicas morfométricas e análise qualitativas de preparados histológicos corados por diferentes métodos associados a técnicas de autofluorescência, o presente estudo mostrou: 1) redução significativa da espessura da epiderme e derme de indivíduos após os 60 anos de idade, sugerindo que esses parâmetros não decrescem de forma contínua, mas decrescem consideravelmente nas últimas décadas de vida; 2) redução progressiva da superfície de contato epiderme-derme ao longo da vida, associada à perda da distribuição em rede das fibras elásticas com sua progressiva fragmentação; 3 ) que a estratégia da autofluorescência, para análise das mudanças ultra-estruturais em relação ao envelhecimento, é importante ferramenta para o estudo detalhado da complexa disposição da rede elástica e sua relação espacial com o colágeno, mostrando redução do entrançamento dos ramos das fibras elásticas em torno dos feixes de colágeno, alterações regionalmente específicas da compactação e da disposição do colágeno e espessamento da membrana basal com o envelhecimento.

\section{REFERÊNCIAS / REFERENCES}

1. Gonçalves AP. Envelhecimento cutâneo cronológico. An Bras Dermatol 1991;66:4S-6S.

2. Trelles MA, Rigau J, Mellor TK, Garcia L. A clinical and histological comparison of flashscanning versus pulsed technology in carbon dioxide laser facial skin resurfacing. Dermatol Surg 1998;24(1):43-9.

3. Lavker RM, Zheng PS, Dong G. Morphology of aged skin. Clin Geriatr Med 1989;5(1): 53-67.

4. Pagnano PMG. Envelhecimento da pele e consequiências. J Bras Psiq 1990;39(1):37-41.

5. Tsuji T, Yorifuji T, Hayashi Y, Hamada T. Light and scanning electron microscopic studies on wrinkles in aged persons' skin. $\mathrm{Br}$ J Dermatol 1986;114(3):329-35.

6. Bernstein EF, Chen YQ, Kopp JB et al. Long-term sun exposure alters the collagen of the papillary dermis. Comparison of sun-protected and photoaged skin by northern analysis, immunohistochemical staining, and confocal laser scanning microscopy. J Am Acad Dermatol 1996;34:209-18.

7. Margelin D, Fourtanier A, Thevenin T, Medaisko C, Breton M, Picard J. Alterations of proteoglycans in ultraviolet-irradiated skin. Photochem Photobiol 1993;58(2):211-8.

8. Ashcroft GS, Greenwell-Wild T, Horan MA, Wahl SM, in the reticular dermis as a function of aging, leading to a predominant horizontalization, following a linear tendency. ${ }^{19}$ The compromising of the superficial and intermediate collagen and of the structure of elastic tissue could thereby contribute to the picture of ptosis and of wrinkling that characterizes old age so well. In agreement with previous works, ${ }^{35}$ this research also identified the increase of autofluorescence in the basal dermoepidermal membrane of senile skin, which could be explained by the growing deposit of a fluorescent component and by the increase of its thickness with age. All of which further reinforces the premise of a deficiency in the turn over of collagen. ${ }^{34}$

\section{CONCLUSION}

Using morphometric techniques and qualitative analysis of histological preparations stained by the various methods associated with autofluorescence techniques, the present study showed: 1) significant reduction of the thickness of the epidermis and dermis in individuals over 60 years of age, suggesting that these parameters do not decrease in a continuous way, but decrease considerably in the last decades of life; 2) progressive reduction of the der-moepidermal contact surface throughout life, associated with the loss of distribution in the elastic fiber network and its progressive fragmentation; 3) that autofluorescence is a useful method for analysis of the ultra-structural changes in relation to aging, because it is an important tool for the detailed study of the complex disposition of the elastic network and its spatial relationship with collagen. It clearly reveals the reduction of the interlacing of the branches of elastic fibers around bundles of collagen, specific regional alterations of compacting and the disposition of collagen in the basal membrane and its thickening during the aging process.

Ferguson MW. Topical estrogen accelerates cutaneous wound healing in aged humans associated with an altered inflammatory response. Am J Pathol 1999;155(4):1137-46.

9. Bischoff JE, Arruda EM, Grosh K. Finite element modeling of human skin using an isotropic, nonlinear elastic constitutive model. J Biomech 2000;33(6):645-52.

10. Castelo-Branco C, Pons F, Gratacos E, Fortuny A, Vanrell JA, Gonzalez-Merlo J. Relationship between skin collagen and bone changes during aging. Maturitas 1994;18(3):199-206.

11. Cruzzi-Maya T, Piñeiro-Maceira J. Dermatopatologia: Bases para o Diagnóstico Morfológico. São Paulo: Roca, 2001.

12. Pinkus H, Mehregan AH, Staricco RG. Elastic globes in human skin. J Invest Dermatol 1965;45(2):81-5.

13. Tsuji T, Hamada T. Age-related changes in human dermal elastic fibres. Br J Dermatol 1981;105(1):57-63.

14. Blair C. Morphology and thickness of the human stratum corneum. Br J Dermatol 1968; 80(7):430-6.

15. Lapière $\mathrm{CM}$. The ageing dermis: the main cause for the appearance of 'old' skin. Br J Dermatol 1990;122 Suppl 35:5-11

16. Kono T, Tanii T, Furukawa M et al. Correlation between ageing and collagen gel contractility of human fibroblasts. Acta Derm Venereol 1990;70(3):241-4. 
17. Martin M, el Nabout R, Lafuma C, Crechet F, Remy J. Fibronectin and collagen gene expression during in vitro ageing of pig skin fibroblasts. Exp Cell Res 1990;191(1):8-13.

18. Maurel E, Bouissou H, Pieraggi MT, Julian M. Age dependent biochemical changes in dermal connective tissue. Relationship to histological and ultrastructural observations. Connect Tissue Res 1980;8(1):33-9.

19. Moragas A, Garcia-Bonafe M, Sans M, Toran N, Huguet P, Martin-Plata C. Image analysis of dermal collagen changes during skin aging. Anal Quant Cytol Histol 1998;20(6): 493-9.

20. Leveque JL, Corcuff P, De Rigal J, Agache P. In vivo studies of the evolution of physical properties of the human skin with age. Int J Dermatol 1984;23(5):322-9.

21. Vitellaro-Zuccarello L, Cappelletti S, Dal Pozzo Rossi V, SariGorla M. Stereological analysis of collagen and elastic fibers in the normal human dermis: variability with age, sex, and body region. Anat Rec 1994;238(2):153-62.

22. Hill MW. Influence of age on the morphology and transit time of murine stratified squamous epithelia. Arch Oral Biol 1988;33(4):221-9.

23. Seidenari S, Giusti G, Bertoni L, Magnoni C, Pellacani G. Thickness and echogenicity of the skin in children as assessed by 20-MHz ultrasound. Dermatology 2000;201(3):218-22.

24. Pienta KJ, Getzenberg RH, Coffey DS. Characterization of nuclear morphology and nuclear matrices in ageing human fibroblasts. Mech Ageing Dev 1992;62(1):13-24.

25. Smith GJ, Davidson EA, Mitchell W et al. Alterations in human dermal connective tissue with age and chronic sun damage. J Invest Dermatol 1962;39(4):347-50.

26. Takeda K, Gosiewska A, Peterkofsky B. Similar, but not identical, modulation of expression of extracellular matrix components during in vitro and in vivo aging of human skin fibroblasts. J Cell Physiol 1992;153(3):450-9.

27. De Faria JC, Tuma Júnior P, Costa MP, Quagliano AP, Ferreira MC. Envelhecimento da pele e colágeno. Rev Hosp Clin Fac Med
São Paulo 1995;50 Suppl:39-43.

28. Kiernan JA. Histological \& Histochemical Methods. 3rd ed. New York: Oxford University Press, 2001.

29. Carvalho HF, Taboga SB, Felisbino SL. Fluorescence and confocal laser scanning microscopy of $\mathrm{H} \& \mathrm{E}$ stained sections for the study of elastic fibers in skin and in some skin disorders. Braz $\mathrm{J}$ Morphol Sci 1999;16(1):97-103.

30. Shuster S, Black MM, McVitie E. The influence of age and sex on skin thickness, skin collagen and density. $\mathrm{Br} \mathrm{J}$ Dermatol 1975;93(6):639-43.

31. Smith L. Histopathologic characteristics and ultrastructure of aging skin. Cutis 1989; 43(5):414-24.

32. Imayama S, Braverman IM. A hypothetical explanation for the aging of skin. Chronologic alteration of the three-dimensional arrangement of collagen and elastic fibers in connective tissue. Am J Pathol 1989;134(5):1019-25.

33. Yamauchi M, Prisayanh P, Haque Z, Woodley DT. Collagen cross-linking in sun-exposed and unexposed sites of aged human skin. J Invest Dermatol 1991;97(5):938-41.

34. Yamauchi M, Woodley DT, Mechanic GL. Aging and crosslinking of skin collagen. Biochem Biophys Res Commun 1988;152(2):898-903.

Vazquez F, Palacios S, Aleman N, Guerrero F. Changes of the basement membrane and type IV collagen in human skin during aging. Maturitas 1996;25(3):209-15.

ENDEREÇO PARA CORRESPONDÊNCIA: / MAILING ADDRESS:

Gerly Anne de Castro Brito

Rua Cel. Nunes de Melo, 1127

Fortaleza CE 60430-970

Tel/Fax: (85) 288-8349 / 288-8333

E-mail: gerlybrito@botmail.com 